7. Lenotr, Zh. (2003). The daily life of Versailles under the kings. Trans. from fr. Moscow: Molodaya gvardiya. [in Russian].

8. Memoirs of Messire d'Artagnan: in 3 vols. Vol. 2. (M. Pozdnyakovoy, Trans. from fr.). (1995). Moscow: «ANTANTA Ltd» [in Russian].

9. Mitford, N. (2003). France. Court life in the era of absolutism. Smolensk: Rusich [in Russian].

10. Moler, Zh.-B. (2009). Complete works in one volume. Trans. from fr. Moscow: Alfa-kniga. URL:http://lib.rus.ec [in Russian].

11. Neklyudova, M.S. (2014). Gallant cartography and representation models of the French court of the mid17th century. French Yearbook 2014: Courtyard Life in France from Charlemagne to Louis XIV. A.V. Chudinova \& Yu.P. Krylovoy (Eds.). Moscow: IVI RAN. Pp. 252-268. [in Russian].

12. Ptifis, Zh.-K. (2008). Lyudovik XIV. Glory and trials. Trans. from fr. SPb.: Yevraziya [in Russian].

13. Rakova, A. (2004). Versailles holidays of the Sun King. SPb.: Izd-vo Gos. Ermitazha [in Russian].

14. Rakova, A. L. (2004). Holiday is the sovereign's favorite toy. Celebrations and festivities in European engraving of the 16th-18th centuries from the Hermitage collection [exhibition catalog]. SPb.: Gos. Ermitazh [in Russian].

15. Rets, cardinal de. (1997). Memoirs. Trans. from fr. Moscow: Ladomir [in Russian].

16. Sabadash, Yu. Humanism as a Phenomenon of Italian Culture. Kyiv: DAKKKiM, 2008. [in Ukraine].

17. Savin, A. (1930). The Century Lyudovik XIV. Moscow: Gos. izd-vo [in Ukraine].

18. Sevine, madam de. (2012). Letters. Trans. from fr. SPb.: Azbuka; Azbuka-Attikus [in Russian].

19. Sen-Simon, gertsog de. (1991). Memoirs: Duke de Saint-Simon's Complete and Authentic Memoirs of Lyudovik XIV and the Regency. Trans. from fr.: in 2 vols. Moscow: Progress, 1991. Vol. 1., Vol. 2 [in Russian].

20. Khenshell, N. (2003). The myth of absolutism: Changes and continuity in the development of the West European monarchy of the early New Age. (A.A. Palamarchuk, L.L. Tsaruk, Yu.A. Malakhova, Trans. from eng.). S.Ye. Fedorov (Ed.). SPb.: Aleteyya [in Russian].

21. Elias, N. (2002). Court Society: Studies on the Sociology of the King and the Court Aristocracy, with an Introduction: Sociology and History. (A. P. Kukhtenkova, K. A. Levinsona, A. M. Perlova, Ye. A. Prudnikovoy, A. K. Sudakova, trans. from germ). Moscow: Yazyki slavyanskoy kultury [in Russian].

22. Erlanzhe, F. (2005). The era of the courts and kings. Etiquette and manners in 1558-1715. Trans. from eng. Smolensk: Rusich [in Russian]. English].

23. Burke, P. (2007). Louis XIV: Les stratégies de la gloire; traduit de l'anglais. Lonrai: Éditions du Seuil [in

24. Felibien A. Les Divertissemens de Versailles, donnez par le Roy au retour de la conqueste de la FrancheComte, en l'annee 1674. URL: http://gallica.bnf.fr/ark:/12148/btv1b8626218b.r=Felibien.langEN. [in English].

25. Louis XIV. (2007). Mémoires. Manière de visiter les jardins de Versailles. Paris: Tallandier [in English].

Стаття надійшла до редакції 5.05.2019 p.

УДК $22.01: 22.06: 226.3: 7.04: 316.73$

\author{
Степанова Олена Анатоліївна \\ доктор культурології, професор, \\ завідувач кафедри туризму, документних \\ та міжкультурних комунікацій \\ Відкритого міжнародного університету \\ розвитку людини «Україна» \\ ORCID 0000-0003-4985-0359 \\ elen_d@i.ua
}

\title{
СЕМІОСФЕРА БІБЛІЙНИХ ОБРАЗІВ: ФУНКЦІОНУВАННЯ В КУЛЬТУРІ
}

\begin{abstract}
Мета статті - дослідження сутності функціонування «мандрівних» біблійних образів у культурі та розкриття ретрансльованих смислів, семантичне ядро яких експлікується на основі наративів Святого Письма, а також попередніх культурних топосів. Методологія дослідження полягає у використанні структурно-семіотичного методу, що дозволяє інтерпретувати семантичні значення окремих біблійних образів та пояснити стратегії їхнього функціонування у культурі. Наукова новизна полягає в дослідженні функціонування біблійних образів у континуумі світової культури, зокрема на прикладі семіосфери постаті святого євангеліста Марка, присутнього у культурних текстах як християнського Сходу, так і Заходу. Проаналізовано функціонування цього християнського образу не тільки у традиційній сакральній культурі (іконографії, музиці), що простежується протягом історії, але й у сучасній популярній культурі. Висновки. Універсальні за своїми смислами біблійні образи функціонують у контексті міжтекстових зв'язків - у різних видах мистецтва, національних культурах, конфесійних спільнотах протягом тривалого хронологічного виміру, включно із сучасністю. Образ євангеліста Марка демонструє, як внутрішній смисловий потенціал цього святого «мандрує» та реінтерпретується, представляючи глибокі смисли євангельського наративу, що постає як семантичне ядро. Розлогі референції семіосфери образу святого Марка створюють складне переплетення «текстів у текстах», впорядкована інтерпретація якого уможливлює осмислене сприйняття.
\end{abstract}

Ключові слова: семіосфера, біблійні образи, культура, текст, святий євангеліст Марк. 
Степанова Елена Анатолиевна, доктор культурологии, профессор, заведующая кафедрой туризма, документных и межкультурных коммуникаций Открытого международного университета развития человека «Украина»

\section{Семиосфера библейских образов: функционирование в культуре.}

Цель статьи - исследование сущности функционирования «странствующих» библейских образов в культуре и раскрытие ретранслируемых смыслов, семантическое ядро которых эксплицируется на основе нарративов Священного Писания, а также предыдущих культурных топосов. Методология исследования заключается в использовании структурно-семиотического метода, позволяющего интерпретировать семантические значения отдельных библейских образов и объяснить стратегии их функционирования в культуре. Научная новизна заключается в исследовании функционирования библейских образов в континууме мировой культуры, в частности на примере семиосферы фигуры святого евангелиста Марка, присутствующего в культурных текстах как христианского Востока, так и Запада. Проанализировано функционирование этого христианского образа не только в традиционной сакральной культуре (иконографии, музыке), что прослеживается на протяжении истории, но и в современной популярной культуре. Выводы. Универсальные по своим смыслами библейские образы фрунционируют в контексте межтекстовых связей - в разных видах искусства, национальных культурах, конфессиональных сообществах в течение длительного хронологического измерения, включая современность. Образ евангелиста Марка демонстрирует, как внутренний смысловой потенциал этого святого «странствует» и реинтерпретуется, представляя глубокие смыслы евангельского нарратива, что выступает в качестве семантического ядра. Широкие референции семиосферы образа святого Марка создают сложное переплетение «текстов в текстах», упорядочена интерпретация которого обеспечивает осмысленное восприятие.

Ключевые слова: семиосфера, библейские образы, культура, текст, святой евангелист Марк.

Stepanova Olena, Doctor of Sciences in Cultural Studies, Professor, Head of the Department of Tourism, Documentary and Intercultural Communication, Open International University of Human Development "Ukraine"

The Semiosphere of Biblical Images: Functioning in Culture.

Purpose of the article is to study the essence of the functioning of "wandering" biblical images in culture and the disclosure of retransmitted senses, the semantic core of which is explicated on the basis of the narratives of the Holy Scriptures, as well as previous cultural topos. The methodology of the research consists of using the structural-semiotic method, which makes it possible to interpret the semantic meanings of individual biblical images and explain the strategies of its functioning in culture. The scientific novelty consists in proving the study of the functioning of biblical images in the continuum of world culture, in particular by the example of the semiosphere of the figure of the Saint Mark the Evangelist, present in the cultural texts of both the Christian East and the West. The functioning of this Christian image is analyzed not only in the traditional sacral culture (iconography, music), which can be traced throughout history but also in modern popular culture. Conclusions. Biblical images that are universal in their meaning function in the context of intertextual relations - in different types of art, national cultures, and confessional communities over a long chronological dimension, including modernity. The image of the Evangelist Mark demonstrates how the inner semantic potential of this saint "travels" and reinterprets, presenting the deeper meanings of the Gospel narrative, which acts as a semantic core. The broad references of the semiosphere of the image of St. Mark create a complex interweaving of "texts in texts," whose orderly interpretation provides a meaningful perception. The analyzed image of St. Mark the Evangelist demonstrates how the inner semantic potential of this figure of Christian history "travels" and reinterprets, presenting the deep meanings of the evangelical narrative that emerges as a semantic core. The linguistic references to the semiosphere of the image of St. Mark create a complex interweaving of "texts in texts," an orderly interpretation of which enables a meaningful perception.

Key words: semiosphere, biblical images, culture, text, Saint Mark the Evangelist.

Актуальність теми дослідження. В сучасній культурі (як академічній, так і масовій) біблійні образи та сюжети є одними із визначальних смислових вузлів, герменевтичне розгортання яких свідчить не тільки про інтелектуальну мандрівку в лабіринти значень, але і й навколо яких творяться в сьогоденні наративи і тексти живопису, літератури, музики, скульптури, кіно тощо. Дослідження біблійних образно-символічних структур важливе, тому що воно розкриває універсальні смисли послання біблійного наративу, простежує континуальність «мандрівних» культурних топосів, а також уможливлює свідому рецепцію реінтерпретованих значень у сучасній культурі.

Аналіз останніх досліджень і публікацій. В аналізі функціонування біблійних образів у культурі, зокрема сучасній, доводиться констатувати, що основні дослідження стосуються іконографії та іконології, які були предметом наукового аналізу багатьох українських та закордонних вчених, серед яких назвемо таких: В. Александрович, О. Богомолець, Л. Борщенко, І. Дундяк, П. Жолтовський, В. Мельник, В. Лєпахін, Л. Міляєва, О. Найден, В. Овсійчук, О. Осадча, В. Откович, Н. Руско, В. Свєнціцька, М. Станкевич, Д. Степовик, Л. Успенський, К. Шенборн, І. Язикова та ін. Більшість праць названих дослідників стосувалися аналізу мистецьких художніх особливостей, а також богословського значення, зважаючи на присутність ікони в церковному благочесті й культі. Завдання ж нашої статті полягає у представленні біблійних образів не у канонічному теологічно-церковному дискурсі чи певних художніх парадигмах, а у більш широкому ракурсі - в культурі як тексті, що продукує нові конотації традиційних образів на основі їхньої внутрішньої семантики, закріпленої у наративі Біблії і традиції Церкви.

Мета дослідження полягає у дослідженні функціонування «мандрівних» біблійних образів у культурі та розкритті ретрансльованих смислів, семантичне ядро яких експлікується на основі наративів Святого Письма, а також попередніх культурних топосів. 
Методологія. У статті використано структурно-семіотичну методологію, за якою у культурі як «вторинній моделюючій системі» «будь-який текст неминуче постає мінімально у двох перспективах, як включений до двох типів контекстів. Із одного погляду, він виступає як однорідний з іншими текстами, з іншого, - як такий, що випадає з ряду, “дивний” і “незрозумілий”» [6, 588-589]. I загалом, усю культуру Юрій Лотман вважає «складно побудованим текстом», що «розпадається на ієрархію "текстів у текстах" і творить складні переплетення текстів» [6, 594]. Така методологічна парадигма дозволить інтерпретувати семантичні значення окремих біблійних образів та пояснити стратегії їхнього фрункціонування у сучасній культурі.

Виклад основного матеріалу. У підходах до читання Біблії одним із найпопулярніших $є$ т. зв. lectio continua, за яким пізнання змісту книг Святого Письма йде від першої до останньої - від Книги Буття до Об'явлення Івана Богослова. Як у поважних біблеїстичних виданнях, так і на різних інтернетресурсах представлені й інші способи біблійної лектури, але перший із названих підходів, на нашу думку, наочно представляє не тільки розвиток наративу священної історії від творіння світу з хаосу та до його кінця з Останнім судом, але й функціонування мандрівних у часопросторі культури образів та сюжетів Святого Письма, континуальність смислів яких виходить далеко поза хронологію фрормування й канонізації книг Біблії.

Про актуальність практичного функціонування в культурі, а, відтак, і комплексного культурологічно-мистецтвознавчого аналізу свідчить той факт, що вони належать не тільки минулим епохам, які відзначалися, зокрема, або теоцентричністю, або традиційним використанням класичного спадку міфології та релігії, але й сьогоденню, духовно-естетичні запити якого також детермінують звернення до образів Святого Письма. Погоджуємося із думкою Леоніда Успенського щодо актуалізації православної ікони в XX столітті, після відомих трагедій минулого віку, не тільки в контексті православної культури, але й західної, де іконообразність стала предметом і наукових студій, і атрибутом релігійного культу та мистецького осмислення: «У ній відкрили дух, незмірно більш високий, ніж свій власний, благонабутий у “просвітництві". Вона сприймається уже не тільки як художня або культурна цінність, але і як художнє одкровення духовного досвіду - “умозріння в фрарбах”, явлене також у роки сум'ять і катастроф» $[10,333]$.

Іван Франко, окрім усіх інших видів наукової та художньої творчості, займався дослідженням апокрифів, зібравши їх у кілька томів на подавши докладні пояснення, володіючи найповнішою на початок XX століття інформацією стосовно цього жанру релігійної літератури. Стосовно окремої групи, яка стосувалася апокрифічних передань про апостолів та їхніх учнів, то Іван Франко відзначив, зокрема: «Кожда важнїйша християнська церков у часї на стілько пізнім, що її початки були вже забуті, бажала мати своїм патроном і основателем якогось апостола або безпосереднього апостольського ученика <..> 3 подібного жерела, зразу побожного бажаня, а далї з конкуренційного інтересу та політичних змагань ріжних церков, виплили льокалїзації дїяльности й мучеництва Марка в Александрії, Варнави в Кипрі, Луки в Тебах, Діонїзія в Парижі, Филипа в Єраполі, Теклі в Селевкії і т. и. Лєґенди сеї категорії, хоч переважно досить пізні (деякі йдуть аж із середнїх віків, прим. Лєґенда про Діонізія в Парижі, про проповідь Якова в Ішпанії, Андрія на Руси), мають переважно значний історичний інтерес, бо за масками тих святих патронів і мучеників ми можемо декуди добачати ті церковно-партійні та культові інтереси, що сплодили собі з часом символ у даній лєґенді» [1, v-vi] (збережено авторський правопис - О.С.). Короткі апокрифи про святого Марка, де розповідається про його мученицьку смерть в Олександрії, також поміщені в кодексі апокрифів Івана Франка [1, 200-205]. На межі XIX-XX століть один із найбільш універсальних європейських науковців того часу Іван Франко, у помітному дусі прихильності до методології позитивізму, відзначає про вплив соціально-політичних детермінант, які можемо відчитати в історичному контексті кінця античності й раннього середньовіччя, на фрормування апостольського апокрифічного корпусу, що вплинув не тільки на наративи церковного передання ортодоксальних церков, але й дієво народжував і формував культурні інтертексти. У такій семіосфрері функціонували ті образи й сюжети, які простежуються впродовж тривалого культурного континууму, творча інтерпретація котрих відбувається і в сьогоденні.

У наведеній цитаті Івана Франка з його кількатомної Biblia apocrypha, ретельно зібраній із давньоукраїнських рукописів, згадується постать святого Марка, на прикладі образу якого і репрезентуємо функціонування біблійних образів у сучасній культурі.

У церковному мистецтві образ святого Марка належить до канону інтер'єрів православного храму. Валерій Лєпахін в аналізі співвідношення синергії та іконообразу відзначає: «Іконообраз - це один із найблагодатніших провідників Божественної енергії. Ікона - синергійна, вона не тільки свідчить про інший світ, не просто показує святість і закликає до віри, але благодаттю, що перебуває на ній, божественною енергією, що ісходить від неї, впливає на людину, втягує ії̈ в іконічне Богоспілкування, яке преображує людину зсередини. При цьому ікона лише тоді починає діяти в усій своїй синергійній повноті, таємничій, але реальній силі, коли людина робить крок до неї, коли відкриває себе для сприйняття благодаті» [5, 83]. У цьому синергійному процесі, на нашу думку, важливе не тільки духовне бачення, остаточною метою якого є сотеріологічна, але інтелектуальна робота, прагнення верифікувати приховані смисли та значення в інтертексті іконообразів. Бібліїсти відзначають таку характеристику оповіді Марка, що, на відміну від інших авторів, він найчастіше використовує і пояснює поняття 
«євангеліє»: «Уже на самому початку св. Марко безпосередньо поєднує Євангеліє з обітницею близького приходу Царства Божого (див. Мр. 1, 14-15). Проповідування цього Євангелія, власне, і є завданням апостолів. Коли Марко саме таким чином говорить про проповідь Ісуса, тим самим вказує на те, що Церква просто продовжує Його місію» [8, 191]. Отже, він чітко розумів і виразно подавав основне завдання Євангелія - проповідь «доброї новини» про Ісуса - Христа та Сина Божого. А в культурному просторі сам образ святого Марка став досить популярним в інтерпретації, яка безпосередньо пов'язана і з авторством його Євангелії.

Згідно середньовічного передання, мощі святого Марка зберігаються у Базиліці святого Марка в Венеції, куди вони були перевезені у IX столітті. Блискучий собор зводився та прикрашався як атрибут сили й багатства Венеційської Республіки, його прикрашали прославлені митці, а сама концепція оздоблення наділена символічними функціями. Святиня покровителя Венеції оздоблена величезною кількістю яскравих мозаїк (серед яких і сцени чудес святого Марка), з якими могли б зрівнятися хіба що константинопольські: це порівняння не випадкове, адже вплив візантійського мистецтва на венеційське виразний [14, 54-58]. Блиск позолоти, смальти, дорогоцінного каміння створює ефект метафізики світла, символізм якого сягає своїм корінням фраворського чуда, яке, зокрема, описав і святий Марк: «А через шість день забирає Ісус Петра, і Якова, і Івана, та й веде їх осібно на гору високу самих. I Він переобразивсь перед ними. I стала одежа Його осяйна, дуже біла, як сніг, якої білильник не зміг би так вибілити на землі! I з'явивсь їм Ілля та Мойсей, і розмовляли з Ісусом. І озвався Петро та й сказав до Ісуса: Учителю, добре бути нам тут! Поставмо ж собі три шатрі: для Тебе одне, і одне для Мойсея, і одне для Іллі... Бо не знав, що казати, бо були перелякані. Та хмара ось їх заслонила, і голос почувся із хмари: Це Син Мій Улюблений, Його слухайтеся! I зараз, звівши очі свої, вони вже нікого з собою не бачили, крім Самого Ісуса» (Мк. 9:2-8).

Практично є підстави інтерпретувати цю наявність золотого кольору зі східнохристиянською традицією ісихазму, вплив якої відобразився, зокрема, і в іконографрії. Ірина Язикова з цього приводу пише: «Світло - одна з основних категорій богослов'я ікони. Через світло катафатика й апофратика ікони віднаходять адекватну форму вираження. Але вчення ісихастів надало переживанню світла в іконі особливу глибину, гостроту та наповненість. У XIV столітті світло, якщо можна так висловитися, стає “головним героєм" іконопису <..> Великого значення для ісихастів мало споглядання Фаворського світла - того світла, яке бачили апостоли під час преображення Господа Ісуса Христа на горі. Через це світло, нетоварне за сутністю, як повчали ісихасти, подвижник входить у спілкування з Неосяжним Богом» [12, 171]. Ймовірно, що прямого потрапляння текстів авторів ісихазму, передусім Григорія Палами, у Венецію не було, тут, радше, можемо зробити висновок про певну спільність духовних шукань митців і богословів, які привели до акцентування на важливості фраворського світла - особливого богословського дискурсу та символу-концепту з євангельського наративу, практичне вираження чого і відобразилося в сяянні християнської іконографії як Сходу, так і Заходу. Окрім того, слід згадати і також тісні зв'язки венеціанців зі східними культурами, що оприявнилося і в самобутньому екзотичнорозкішному та містично-піднесеному мистецтві міста святого Марка.

У традиційній, зокрема для України, хрестово-купольній формі церковної архітектури під центральним барабаном розміщують ікони чотирьох євангелістів - Матвія, Марка, Луки й Івана, кожен із яких зображений зі своїм символом-атрибутом. Святий Марк традиційно представляється разом 3 образом лева, семантика якого, звісно, стосується характеристик його Євангелії. Цей же зооморфний образ повсюдно присутній і у Венеції як ії традиційний символ. Походження чотирьох істот, що стали символами євангелістів, слід шукати у містичних візіях пророка Єзекиїла (1:1-14) та Одкровенні Івана Богослова (Од. 4:6-8), образність яких, в свою чергу, була запозичена з міфологічно-релігійної картини світу вавилонян, з якими євреї мали прямі культурні контакти: в універсальному порядку на небесній дорозі, якою мандрують планети, поміщувалися образи Бика, Лева, Орла (замість Скорпіона, що мав негативне значення) і Людини (Водолія), що представляли чотири сторони світу; вони ж символізували чотири пори року (Бик - весна, Лев - літо, Орел - осінь, Людина - зима). В асирійськовавилонському мистецтві, яке свого часу було невід'ємною частиною релігійних ритуалів, зустрічаються гібриди цих постатей як ідеальне поєднання рис - бики та леви з чотирма крилами і людським обличчям або головою орла й шістьома крилами. Ось як зображає Єзекиїл в своїй містичній візії: «I побачив я, аж ось бурхливий вітер насував із півночі, велика хмара та палючий огонь; а навколо неї сяйво, а з середини його ніби блискуча мідь, з-посеред огню. А з середини його подоба чотирьох живих істот, а оце їхній вид: вони мали подобу людини. I кожна мала чотири обличчі, і кожна з них мала чотири крилі. А їхня нога нога проста, а стопа їхньої ноги як стопа телячої ноги, і вони сяяли, як ніби блискуча мідь. А під їхніми крилами були людські руки на чотирьох сторонах їхніх, і вони четверо мали свої обличчя та свої крила. Їхні крила прилягали одне до одного, не оберталися в ході своїй, кожне ходило просто наперед себе. А подоба їхнього обличчя обличчя людини та обличчя лева мали вони четверо з правиці, а обличчя вола мали вони четверо з лівиці, і обличчя орла мали вони четверо. А їхні обличчя та їхні крила були розділені вгорі; у кожного двоє крил злучувалися одне з одним, і двоє закривали їхнє тіло» (Єз. 1:4-11). До речі, тетраморфне зображення, відповідно до містичного видіння Єзекиїла, збереглося в соборі Святого Марка на колонах тебарнакуля (дарохранительниці) - як символ єдності чотирьох євангелій. У ранньому середньовіччі було розділено між євангелістами ці містич- 
ні образи: Марк отримав лева, тому що його Євангелія починається з опису перебування Івана Хрестителя в пустелі [13, 324-327].

У сучасній масовій культурі біблійний за ґенезою образ лева присутній і у цілком секулярному просторі, зокрема як нагорода (італ. Leone d'Oro) Венеційського кінофестивалю у межах проведення Венеційського бієнале. Тут семіотичний аналіз дозволяє розкрити архаїчні релігійні символи у сучасній популярній культурі. Звісно, що кінонагорода пов'язана з символом міста Венеція, а вже семантичний ланцюжок розгортання значень образу лева веде нас до євангеліста Марка [7, 21].

В епоху бароко постаті євангельських персонажів увійшли також і в музичну культуру, зокрема, якщо вести мову про євангелістів, в жанр т. зв. «страстей», чи «пасій», який довів до вершини свого розвитку Й. С. Бах, - монументальних музичних творів, в яких сюжет про страждання Ісуса Христа виконується із чергуванням коротких арій, хорового виконання і хоралів. Ці доволі тривалі за часом виконання музичні твори виконувалися як частина літургійного театру під час протестантського богослужіння у Страсний тиждень (особливо у Велику п'ятницю), а між їхніми частинами виголошувалася проповідь пастора, щоб пояснити те, що передавалося мовою музики. Ці музичні бахівські «пасійні» апокрифи були особливою частиною культури бароко з ії розлогим символізмом і неспішною наративністю. До речі, про «Страсті за Марком» дослідникам творчості Й. С. Баха небагато відомо, там чимало лакун, які заповнюються сучасними інтерпретаторами [4, 237-251]. На нашу думку, в цьому доволі екзотичному як для сьогодення музичному складному жанрі образ євангеліста Марка, а передусім його євангельського наративу про страждання Ісуса Христа, передавався й інтерпретувався музичними виражальними засобами, фактично продовжуючи «відкритість» тексту Нового Завіту та виступаючи видом барокової культурної адаптації, що передбачає пристосування до соціально-історичних умов, зокрема, й механізми комунікації $[3,17]$ до відповідної культурної парадигми (тут маємо справу зі світом бароко), адже «творчість $є$ трансформуванням уявно-образного мислення у конкретну культурологічну діяльність» [11, 82]. Віктор Бичков у дослідженні адаптації музичного мистецтва античності у християнській культурі Візантії зауважує таку ії характеристику, яка може бути використано як загальна риса всієї духовної музики, котра раніше створювалася для потреб церковного вжитку, відповідно до літургійного календаря, а сьогодні сприймається як спадщина класичного музичного мистецтва: «Музика не тільки відповідним чином настроює душі людей, але вона виступає також образом, символом, знаком душевних станів <...> Музика (або мелодія) виникає як відображення відповідного настрою душі i, в свою чергу, впливає на душу, керуючи ії порухами» [2, 122-123].

Як бачимо, структурно-семіотичний аналіз біблійних образів, зокрема постаті святого євангеліста Марка, дозволяє актуалізувати й розшифрувати ретрансльований протягом історії культури зміст інтерпретацій.

Наукова новизна. Вперше, використовуючи структурно-семіотичну методологічну базу, досліджено фрункціонування «мандрівних» біблійних образів у континуумі світової культури, зокрема на прикладі семіосфери постаті святого євангеліста Марка, присутнього у культурних текстах як християнського Сходу, так і Заходу. Досліджено функціонування цього християнського образу не тільки у традиційній сакральній культурі, що простежується протягом історії, але й у сучасній популярній культурі.

Висновки. Біблійні образи, універсальний вимір внутрішньої змісту яких виходить поза межі культурного світу, в якому вони виникли, репрезентують собою функціонування у контексті міжтекстових зв'язків - у різних видах мистецтва, національних культурах, конфесійних спільнотах протягом тривалого хронологічного виміру, включно із сучасністю. Проаналізований образ святого євангеліста Марка демонструє, як внутрішній смисловий потенціал цієї постаті християнської історії «мандрує» та реінтерпретується, представляючи глибокі смисли євангельського наративу, що постає як семантичне ядро. Розлогі референції семіосфери образу святого Марка створюють складне переплетення "текстів у текстах», впорядкована інтерпретація якого уможливлює осмислене сприйняття. На нашу думку, використання запропонованого у статті методологічного підходу $є$ перспективним у культурологічних, мистецтвознавчих дослідженнях, а також в інших галузях науки, оскільки демонструє універсальність смислів, які реінтерпретуються впродовж історії культури завдяки семантичному ядру образів, одним із найбільших джерел яких постає Біблія, що своїм наративом конституювала численні текстові поєднання.

\section{תimepamypa}

1. Апокрифи і легенди з українських рукописів / Зібрав, упорядкував і пояснив др. Іван Франко. Т.ІІІ. Апокрифи новозавітні. Б. Апокрифічні діяння апостолів: Репринт видання 1902 року. Львів: Львівський національний університет імені Івана Франка, 2006. 456 с.

2. Бычков В. В. Древнерусская эстетика. СПб.: Центр гуманитарных инициатив, 2012. 832 с.

3. Герчанівська П. Е. Культурологія: термінологічний словник. К.: НАКККіМ, 2015. 439 с.

4. Друскин М. С. Иоганн Себастьян Бах. М.: Музыка, 1982. 383 с.

5. Лєпахін В. Ікона та іконічність / Пер. з рос. Т. Тимо. Львів: Свічадо, 2001. 288 с.

6. Лотман Ю. Текст у тексті ; [пер. з рос. Я. Приходи]. Антологія світової літературно-критичної думки XX ст. . Львів: Літопис, 2001. с. 588-589. 
7. Остащук І. Б. Християнський сакральний символізм: релігієзнавчо-фрілософрський дискурс : монографія . К.: Автограф, 2011. 288 c.

8. Свідеркувна А. Розмови про Біблію: Новий Завіт / Пер. з пол. Тарас Різун. Львів: Свічадо, 2009. 372 с.

9. Святе Письмо Старого та Нового Завіту. Повний переклад, здійснений за оригінальними єврейськими, арамійськими та грецькими текстами. United Bible Societies, 1991. 1494 с.

10. Успенский Л. А. Богословие иконы Православной Церкви. Изд. 2-е. М.: ДАРЪ, 2008. 480 с.

11. Шульгіна В., Рябінко С. Творча діяльність особистості у системі мистецької освіти України: європейський контекст // Вісник НАКККіМ. 2017. № 1. с. 80-85.

12. Языкова И. Со-творение образа. Богословие иконы. М.: Издательство ББИ, 2012. 368 с.

13. Forster D., OSB. Świat symboliki chrześcijańskiej: leksykon. Warszawa: Instytut Wydawniczy Pax, 2001. $544 \mathrm{~s}$.

14. Treasures of Venice. Venezia: Storti Edizioni, 2009. 174 p.

\section{References}

1. Apocrypha and legends from Ukrainian manuscripts (2006). Collected, compiled and explained Dr. Ivan Franko. T.III. Apocrypha of New Testament. B. Apocryphal Acts of the Apostles: Reprint Edition, 1902. Lviv: Ivan Franko National University of Lviv [in Ukrainian].

2. Bychkov, V. (2012). Old Russian aesthetics. St. Petersburg: Tsentr humanitarnykh initsyativ [in Russian].

3. Gerchanivska, P. (2015). Cultural Studies: Thermological Dictionary. Kyiv: HAKKKiM [in Ukrainian].

4. Druskin, M. (1982). Johann Sebastian Bach. Moscow: Muzyka [in Russian].

5. Lepakhin, V. (2001). Icon and Iconicity (trans. T. Tymo). Lviv: Svichado [in Ukrainian].

6. Lotman, Yu. (2001). Text in the text (trans. Ya. Prykhoda). Anthology of the world literary-critical thought of the twentieth century. Lviv: Litopys. pp. 588-589. [in Ukrainian].

7. Ostashchuk, I. (2011). Christian sacred symbolism: Religious and philosophical discourse: monograph. Kyiv: Autograph [in Ukrainian].

Ukrainian].

8. Sviderkuvna, A. (2009). Talk about the Bible: The New Testament (trans. Taras Rizun). Lviv: Svichado [in

9. The Bible of the Old and New Testament (1991). Full translation of the original Hebrew, Aramaic and Greek texts. United Bible Societies [in Ukrainian].

10. Ouspensky, L. (2008). The theology of icons of the Orthodox Church. $2^{\text {nd }}$ Ed. Moscow: DAR. [in Russian].

11. Shulgina V., Ryabinko S. (2017). Creative Activity of the Individual in the System of Art Education in Ukraine: European Context. National Academy of Managerial Staff of Culture and Arts Herald. № 1. pp. 80-85 [in Ukrainian]

12. Yazykova, I. (2012). Co-creation of the image. The theology of icons. Moscow: Ed. BBI [in Russian]. Polish].

13. Forster, D., OSB (2001). The world of Christian symbolism: lexicon.Warsaw: Instytut Wydawniczy Pax [in

14. Treasures of Venice. Venezia: Storti Edizioni, (2009) [in English].

Стаття надійшла до редакції 17.08.2019 p. 